\title{
Folate metabolism and the risk of Down syndrome
}

\section{David Patterson}

Folate is an important vitamin that contributes to cell division and growth and is therefore of particular importance during infancy and pregnancy. Folate deficiency has been associated with slowed growth, anaemia, weight loss, digestive disorders and some behavioural issues. Adequate folate intake around the time of conception and early pregnancy can reduce the risk of certain problems including neural tube defects. It has been suggested that certain versions (polymorphisms) of some genes can increase the risk of conceiving a baby with Down syndrome. If this is the case, then people with Down syndrome may be more likely to carry these forms of these genes and to experience associated problems in folate metabolism. Studies to date have found conflicting results, suggesting that these gene variants may be part of a more complex picture. In this issue, a further study reports no association between the presence of a common polymorphism of one of these genes and the risk of having a child with Down syndrome among mothers of Northern Indian origin. This article reviews these challenging findings and looks at where investigations can now go to resolve these issues.

\section{Introduction}

Folate is a vital vitamin that is found in meat, green vegetables, fruits and beans. The synthetic form added to foods and found in supplements is known as folic acid. Folate plays an essential role in several complex metabolic pathways, including those leading to the synthesis of DNA and RNA and those involved in methylation. Folate deficiency has been associated with slowed growth, anaemia, weight loss, digestive disorders and some behavioural issues. Lowered folate has also been associated with increased risks of neural tube defects and folic acid supplementation is now commonly recommended during early pregnancy, pre- and post-conception.

Many genes are involved in these metabolic pathways. In 1999, Jill James and colleagues ${ }^{[1]}$ reported that a particular variant (polymorphism) of one of these genes (methylenetetrahydrofolate reductase; MTHFR) might be a maternal risk factor for having a child with Down syndrome and that a significant increase in plasma homocysteine levels exists in mothers of children with Down syndrome. This polymorphism is known to decrease the activity of MTHFR ${ }^{[2,3]}$. This report stimulated considerable research into the possible significance of polymorphisms in MTHFR and other enzymes involved in one carbon and transsulfuration (1C/TS) metabolism (FIGURE 1) in mothers and affected individuals with Down syndrome in altering the likelihood of birth of a child with Down syndrome (TABLE 1). This issue remains unresolved. In this issue, Kohli et al. ${ }^{[22]}$ make a contribution to this debate. They find that the C677T MTHFR polymorphism is not associated with increased risk of having a child with Down syndrome in young mothers of Northern Indian origin. They also measured plasma homocysteine levels and found these to be lower in mothers of children with Down syndrome than in mothers of children without Down syndrome. This manuscript presents an opportunity to consider the current status of work in this field and to offer some thoughts on the future of studies to resolve the remaining issues.

Since the initial report of James ${ }^{[1]}$ there have been at least 19 studies on possible polymorphisms not only in the MTHFR gene but also in genes encoding other enzymes of $1-\mathrm{C} / \mathrm{TS}$ metabolism. These all included studies of the MTHFR gene, and many included studies of an additional MTHFR polymorphism, A1298C. Studies have been carried out on populations from North America, Brazil, Ireland, Denmark, France, Italy (Southern and Central), Spain, Japan, and Turkey in addition to India (TABLE 1). Indeed, two additional studies have been carried out on the Indian population, one from Eastern India and one from Western India ${ }^{[11,18]}$. A number of investigators now report that individual polymorphisms may be insufficient to cause an increased incidence of births of children with Down syndrome, but that a genotype in which two or more polymorphisms in different enzymes of the pathways may lead to increased incidence. Interestingly, some investigators are reporting that the presence of two polymorphisms in MTHFR, C677T and A1298C, when present together, lead to an increased risk. This includes a recent study from Rai et al., ${ }^{[18]}$ on a population from Eastern India. Many investigators also hypothesise that there is a strong environment (primarily diet)-genotype interaction that makes studies difficult to compare and interpret.

To help unravel this situation, many investigators have begun to measure metabolites of 1-C/TS pathways, notably homocysteine levels. The rationale for this measurement is that abnormal or altered folate metabolism, including alterations caused by gene polymorphisms, can result in elevated homocysteine levels. Here again, the situation is unclear, since different investigators have reported that homocysteine levels are elevated, unchanged, or decreased in mothers of children with Down syndrome (TABLE 1). 


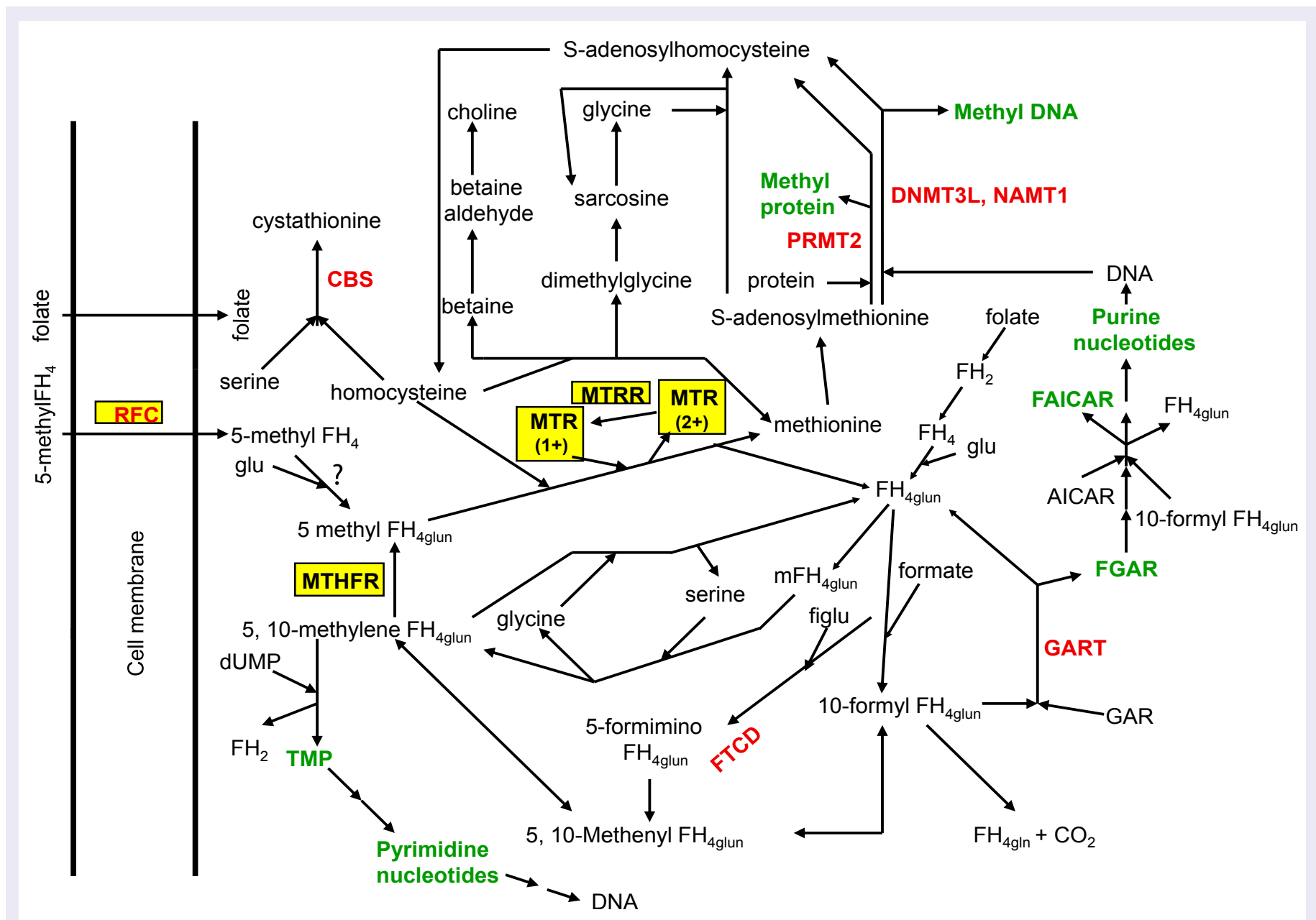

Figure 1 | A Representation of One Carbon and Transsulfuration Metabolism. Enzymes indicated in bold and highlighted in yellow have been found in some studies to influence incidence of births of children with Down syndrome. Enzymes in red are encoded by genes on chromosome 21. Compounds indicated in green are some of the products of methylation reactions critical for cell survival, replication, and function. The ? indicates that the quantitative significance of this reaction is not clear. Abbreviations: MTHFR, methylenetetrahydrofolate reductase; MTR, methionine synthase; MTRR, methionine synthase reductase; $\mathrm{FH}_{2}$, dihydrofolate; $\mathrm{FH}_{4}$, tetrahydrofolate; glun, polyglutamates; TMP, thymidine monophosphate; dUMP, deoxyuridine monophosphate; figlu, formiminoglutamate; GAR, phosphoribosylglycineamide; FGAR, phosphoribosylformylglycineamide; AICAR, phosphoribosylaminoimidazole carboxamide; FAICAR, phosphoribosylformylaminoimidazole carboxamide; NAMT1, putative N6-DNA methyltransferase; RFC, reduced folate carrier; GART, phosphoribosylglycineamide transformylase; PRMT2, protein arginine N-methyltransferase 1 like-1; DNMT3L, DNA methyltransferase 3-like; CBS, cystathionine beta synthase; FTCD, formiminotetrahydrofolate cyclodeaminase;

One interesting hypothesis regarding these observations is that folate can lower homocysteine levels so that dietary supplementation with folate might be expected to result in decreased incidence of births of children with Down syndrome, if elevated homocysteine is indeed associated with an increased incidence. Even here, the situation is unclear. Because perinatal folate supplementation has been shown to decrease the incidence of births with neural tube defects, some countries, notably the United States, have mandated supplementation of wheat flour based products with folic acid for a number of years (since 1998 in the United States). Therefore, it has been possible to examine the incidence of births of children with Down syndrome both prior to and after supple- mentation was initiated, and to check the effectiveness of supplementation by measuring folate levels in individuals pre- and post initiation of supplementation. When this is done, an elevation of serum and red blood cell folate is indeed observed post supplementation. However, there is no evidence of a decreased incidence of births of children with Down syndrome, and some studies actually provided evidence for a slight increase in incidence of births of children with Down syndrome, while other studies report no changes pre- and post- supplementation ${ }^{[23,24,25,26]}$ On the other hand, one report on maternal use of iron and folate during the first month of pregnancy indicates that folate use might decrease the incidence of births with Down syndrome ${ }^{[27]}$. In this case, folate tablets were taken, and the dose was higher than is likely to be attained by supplementation of the food supply.

Some investigators have pointed out that altered folate metabolism might be expected to affect meiosis. This may present an added complexity to these studies, since about two-thirds of the non-disjunction events resulting in Down syndrome occur in meiosis I and therefore may occur, or at least be initiated, during the foetal development of the mother. This may mean that it would be the maternal grandmother whose genotype and diet might be significant. This information is essentially impossible to obtain ${ }^{[28,29,30]}$.

Another possible complexity is that there are at least 7 genes on chromosome 21 that could be important for 1-C/TS 


\begin{tabular}{|c|c|c|c|c|c|c|c|}
\hline Year & Reference & Ethnicity & MTHFR 677 & MTHFR A1298C & Other & MTHFR + other & maternal $\mathrm{HCY}$ \\
\hline 1999 & James $^{[1]}$ & North Am & T allele & & & & $\mathrm{HIGH}$ \\
\hline 2000 & Hobbs $^{[4]}$ & USA & T allele & & MTRR 66G & MTRR 66G + MTHFR 677T & \\
\hline 2000 & $\begin{array}{l}\text { Petersen } \\
{\text { (Abstract) }{ }^{[5]}}^{[5]}\end{array}$ & Denmark & No difference & & & & $\begin{array}{l}\text { HIGH } \\
\text { with T allele }\end{array}$ \\
\hline 2002 & $\mathrm{O}^{\prime}$ Leary $^{[6]}$ & Irish & No difference & & MTRR 66G & MTRR 66GG + MTHFR 677T & No difference \\
\hline 2002 & $\begin{array}{l}\text { Chadefaux- } \\
\text { Vekemans }^{[7]}\end{array}$ & French & No difference & & & & No difference \\
\hline 2002 & Grillo $^{[8]}$ & Brazil & T allele & Callele & & MTHFR 667T + MTHFR 1298C & \\
\hline 2002 & Stuppia ${ }^{[9]}$ & Italian (central) & No difference & & & & \\
\hline 2003 & Bosco $^{[10]}$ & Sicily & No difference & & MTR 2756G & & $\mathrm{HIGH}$ \\
\hline 2003 & Seth and Seth ${ }^{[11]}$ & Indian (western) & No difference & & & & HIGH \\
\hline 2004 & Takamura $^{[12]}$ & Japan & No difference & No difference & & & $\mathrm{HIGH}$ \\
\hline 2004 & Boduroglu ${ }^{[13]}$ & Turkish & $\begin{array}{l}\text { No difference } \\
\text { (trend*) }\end{array}$ & & & & \\
\hline 2005 & da Silva ${ }^{[14]}$ & Brazil & Tallele & & & & HIGH \\
\hline 2005 & Chango $^{[15]}$ & French & No difference & & & & \\
\hline 2005 & Acacio $^{[16]}$ & Brazil & No difference & No difference & & MTHFR 677T + MTHFR $1298 C$ & \\
\hline 2006 & Coppede $^{[17]}$ & Italian (central) & No difference & & & $\begin{array}{l}\text { MTHFR } 677 T T+\text { RFC } 80 G G \\
\text { MTHFR 1298AA + RFC 80GA, } \\
\text { AA down }\end{array}$ & \\
\hline 2006 & $\operatorname{Rai}^{[18]}$ & $\begin{array}{l}\text { Indian (eastern) } \\
\text { Indian (western) }\end{array}$ & Tallele & Callele & & MTHFR 677T + MTHFR 1298C & \\
\hline 2006 & Scala ${ }^{[19]}$ & $\begin{array}{l}\text { Italian } \\
\text { (southern) }\end{array}$ & No difference & Callele & RFC 80G & $\begin{array}{l}\text { MTHFR } 677 \text { T + MTHFR } 1298 C \\
\text { MTHFR } 1298 C+\text { RFC } 80 G\end{array}$ & No difference \\
\hline 2006 & Martinez-Frias ${ }^{[20]}$ & Spanish & $\begin{array}{l}\text { Complex } \\
\text { interaction }\end{array}$ & $\begin{array}{l}\text { Complex } \\
\text { interaction }\end{array}$ & MTRR 66G & $\begin{array}{l}\text { MTHFR 677T + MTHFR 1298C } \\
\text { +MTRR 66G }\end{array}$ & Variable \\
\hline 2007 & Scala ${ }^{[21]}$ & $\begin{array}{l}\text { Italian } \\
\text { (southern) }\end{array}$ & No difference & & & & \\
\hline 2008 & Kohli $^{[22]}$ & Indian (north) & No difference & & & & LOW \\
\hline
\end{tabular}

metabolism (TABLE 2). Trisomy of these genes could well affect 1-C/TS metabolism. Genes encoding proteins that utilise reduced folate moieties might increase folate demand and in principle lead to functional folate deficiency in developing foetuses with Down syndrome. If the mother has impaired folate metabolism, it would then be the interaction of the mother and the developing foetus that would be of critical importance. Such an interaction has been hypothesised on the basis of preferential transmission of the MTHFR 677T allele to infants with Down syndrome ${ }^{[31]}$. From TABLE 2, it is possible that NAMT1 (PRED28), GART, DNMT3L, and HRMT1L1 (PRMT2) could increase demand for 1-C units supplied by folate cofactors. However, recent studies suggest that only GART is likely to be of major importance. Ratel et al., ${ }^{[32]}$ find evidence that methylated adenine is undetectable in mammalian DNA using an assay that could detect one methylated adenine/million DNA nucleotides. Moreover, they failed to detect any methylating function in the NAMT1 protein. DNMT3L is expressed in very limited developmental periods and only in a small number of tissues and has no methylating activity of its own. It enhances the activity of other DNA methylating enzymes [33]. Hence, it seems that it would not cause a significant increase in the need for 1-C groups. On the other hand, PRMT2 apparently does have protein methylating activity $^{[34]}$. GART is a part of the de novo purine biosynthetic pathway, and trisomy of this gene may indeed elevate the need for 1-C units. Interestingly, individuals with Down syndrome have elevated purine levels in bodily fluids and this has been hypothesised to be due to trisomy of GART and resultant increased synthesis of purines ${ }^{[35,36]}$.

A number of investigators have speculated on the trisomy of the gene for cystathionine beta synthase (CBS), located on chromosome 21 , in the possible role of enzyme polymorphisms and dietary response to folates ${ }^{[15,20,31,37,38]}$. CBS synthesises cystathionine from homocysteine and serine. Alternatively, homocysteine reacts with 5 methylFH $_{4 \text { glun }}$ to produce methionine and $\mathrm{FH}_{\text {glun }} .5$-methylFH ${ }_{4 \text { glun }}$ is considered a "methyl trap" because in the absence of homocysteine and/or a decrease in methionine synthase enzyme, it accumulates and cannot re-enter the 1$\mathrm{C} / \mathrm{TS}$ metabolic pathway. Lowered levels of serine, considered by many investigators to be a major methyl group donor through the action of serine hydroxymethyltransferase (SHMT), would also potentially decrease the supply of reduced $\mathrm{FH}_{4 \mathrm{glun}}$ compounds. 


\begin{tabular}{|c|c|c|}
\hline Gene & $\begin{array}{l}\text { Possible effect on 1-C/TS } \\
\text { Metabolism }\end{array}$ & Comments \\
\hline Putative N6-DNA methyltransferase (NAMT1, PRED28) & Increased demand? & Probably not active in methylation \\
\hline Phosphoribosylglycineamide transformylase (GART) & Increased demand & $\begin{array}{l}\text { Purine synthesis (purine levels increased in Down } \\
\text { syndrome }\end{array}$ \\
\hline Cystathionine beta synthase (CBS) & Decreased availability & Mutations lead to human disorders \\
\hline DNA methyltransferase 3-like (DNMT3L) & Increased demand & $\begin{array}{l}\text { No inherent methylation activity, activates other DNA } \\
\text { methyltransferases }\end{array}$ \\
\hline Reduced folate carrier (RFC, SLC19A1) & Increased availability & Also important for folate analogue activity \\
\hline Formiminotetrahydrofolate cyclodeaminase (FTCD) & Increased availability & Mutations lead to human disorders \\
\hline $\begin{array}{l}\text { Protein arginine } \mathrm{N} \text {-methyltransferase } 1 \text { like- } 1 \text { (HRMT1L1, } \\
\text { PRMT2) }\end{array}$ & Increased demand & Probably active in protein methylation \\
\hline
\end{tabular}

Table 2 | Genes on Chromosome 21 Involved in One Carbon/Transsulfuration Metabolism

Another important gene located on chromosome 21 encodes the reduced folate carrier (RFC), widely considered to be quantitatively one of the most significant proteins involved in uptake of reduced folates from the diet and in cellular internalisation of reduced folates ${ }^{[39]}$. Indeed some investigators have looked for an association of polymorphisms in the RFC gene and the risk of birth of a child with Down syndrome $e^{[15,17,18,19,21]}$. In some reports, a G80A polymorphism in RFC, when present with the MTHFR polymorphism does seem associated with an increased incidence of births with Down syndrome ${ }^{[17,19]}$. Increased RFC protein levels have been reported in foetuses with Down syndrome, so trisomy of this gene could increase the availability of reduced folates from the diet ${ }^{[40]}$. The gene for glutamate formiminotransferase (FTCD) is located on chromosome 21 . This enzyme catalyses the synthesis of 5, 10 methenylF$\mathrm{H}_{\text {4glun }}$ from formiminoglutamate (FIGLU) and $\mathrm{FH}_{4 \mathrm{llun}}$. Thus, it might increase the availability of 1-C units. Indeed, reduced levels of FIGLU have been found in the amniotic fluid of pregnancies with Down syndrome ${ }^{[37]}$.

Thus, an added complexity to the genotype of the mother is the possible effect of trisomy of these genes in the foetus with Down syndrome. In some cases, in principle, trisomy of these genes may have opposite effects, most notably for example trisomy for CBS may be hypothesised to decrease the availability of functional 1-C folate units, while trisomy of RFC may be hypothesised to increase the availability of these units.

How can this situation be sorted out? Some suggestions are the following. It may be necessary to extend analysis of the effects of the observed polymorphisms to include more metabolites of the 1-C/ TS pathway, for example, at a minimum total serum and red blood cell folate levels. More informative would be analyses of the quantitative levels of all the folate compounds and related compounds, for example S-adenosyl homocysteine and S-adenosyl methionine. In this way one might be able to compensate for inevitable differences in diet and unknown or undetected polymorphisms in other genes encoding enzymes in 1-C/TS metabolism that are inherent in studies on humans. The concept here is that for polymorphisms to be of significance, they would almost certainly have to have a metabolic effect. What one would look for is a similar change in metabolism in cases of births of individuals with Down syndrome, a "metabolic signature" if you will, that could arise by a variety of different genetic or dietary alterations. Methods for combined genotyping and 1-C/TS metabolic phenotyping are being developed $^{[41,42]}$. These might be considered targeted metabolomic approaches. At another level of complexity, as is well recognised 1-C/TS metabolism is implicated in a wide variety of metabolic systems. It may be useful to apply the approaches of global metabolomic analysis to this problem.

Another possible approach is to undertake studies in mouse models. Mouse models exist for CBS, MTHFR, and RFC at least, and some studies have been undertaken. Mice offer the obvious advantages that diet and genotype can be rigorously controlled. Moreover, additional mouse models of relevance are being generated. For example, mutations corresponding to human polymorphisms in RFC and other genes implicated in humans can be produced. Clearly, the disadvantage is that it is not clear the extent to which observations in mice will be relevant to the human situation.

Fortunately, methods to apply all these approaches to this vexing problem are available and are rapidly becoming more accessible to researchers. It is likely that a combination of all the above approaches will be required. Since many investigators have hypothesised that alterations in 1-C/TS metabolism may play a role in the development of the intellectual disabilities, cardiac abnormalities, and increased risk of leukaemia seen in individuals with Down syndrome, it seems likely that understanding this crucial metabolic system will have dividends that extend far beyond unravelling the roles this metabolic system plays in altering the incidence of births of individuals with Down syndrome.

\section{Acknowledgements}

The author acknowledges the generous support of the Bonfils-Stanton Foundation, the Towne Foundation, and the Lowe fund of the Denver Foundation. David Patterson is at the Eleanor Roosevelt Institute and Department of Biological Sciences, University of Denver, Colorado, USA.

doi: 10.3104/updates.2051 
1. James SJ, Pogribna M, Pogribny IP, Melnyk S, Hine RJ, Gibson JB, Yi P, Tafoya DL, Swenson DH, Wilson VL, Gaylor DW. Abnormal folate metabolism and mutation in the methylenetetrahydrofolate reductase gene may be maternal risk factors for Down syndrome. American Journal of Clinical Nutrition. 1999;70:495-501.

2. Kang SS, Wong PW, Susmano A, Sora J, Norusis $M$, Ruggie N. Thermolabile methylenetetrahydrofolate reductase: an inherited risk factor for coronary artery disease. American Journal of Human Genetics. 1991;48(3):536-545.

3. Goyette $P$, Rozen R. The thermolabile variant $677 \mathrm{C} \rightarrow$ T can further reduce activity when expressed in cis with severe mutations for human methylenetetrahydrofolate reductase. Human Mutation. 2000;16(2):132-138.

4. Hobbs CA, Sherman SL, Yi P, Hopkins SE, Torfs $C P$, Hine RJ, Pogribna M, Rozen R, James SJ. Polymorphisms in genes involved in folate metabolism as maternal risk factors for Down syndrome. American Journal of Human Genetics. 2000;67:623-630.

5. Petersen M, Grigoriadou M, Mikkelsen M. A common mutation in the methylenetetrahydrofolate reductase gene is not a risk factor for Down syndrome. American Journal of Human Genetics. 2000;67(Supplement 2):141.

6. O'Leary VB, Parle-McDermott A, Molloy AM, Kirke PN, Johnson Z, Conley M, Scott JM, Mills JL. MTRR and MTHFR polymorphism: link to Down syndrome? American Journal of Medical Genetics. 2002;107:151-155.

7. Chadefaux-Vekemans B, Coude M, Muller F, Oury JF, Chabli A, Jais JP, Kamoun P. Methylenetetrahydrofolate reductase polymorphism in the etiology of Down syndrome. Pediatric Research. 2002;51(6):766-767.

8. Grillo LBN, Acacio GL, Barini, R. Pinto, W, Bertuzzo CS. Mutacoes no gene da metilenotetrahidrofolato reductase e sindrome de Down. Cad. Saude Publica, Rio de Janeiro. 2002;18(6):17951797.

9. Stuppia L, Gatta V, Gaspari AR, Antonucci I, Morizio E, Calabrese G, Palka G. C677T mutation in the 5, 10-MTHER gene and risk of Down syndrome in Italy. European Journal of Human Genetics. 2002;10:388-390.

10. Bosco P, Gueant-Rodriguez R-M, Anello G, Barone C, Namour F, Caraci F, Romano A, Romano C, Gueant J-L. Methionine synthase (MTR) 2756 $(A \rightarrow G)$ polymorphism, double heterozygosity methionine synthase $2756 \mathrm{AG}$ /methionine synthase reductase (MTRR), and elevated homocysteine are three risk factors for having a child with Down syndrome. American Journal of Medical Genetics Part A. 2003;121:219-224.

11. Sheth JJ, Sheth FJ. Gene polymorphism and folate metabolism: a maternal risk factor for Down syndrome. Indian Pediatrics. 2003;40:115123.

12. Takamura N, Kondoh T, Ohgi S, Arisawa K Mine M, Yamashita S, Aoyagi K. Abnormal folic acid-homocysteine metabolism as maternal risk factors for Down syndrome in Japan. European Journal of Nutrition. 2004;43(5):285-287.

13. Boduroglu K, Alanay Y, Koldan B, Tuncbilek E. Methylenetetrahydrofolate reductase enzyme polymorphisms as maternal risk for Down syndrome among Turkish women. American Journal of Medical Genetics Part A. 2004;127:5-10.

14. da Silva LRJ, Vergani N, Galdieri LC, Porto MPR, Longhitano SB, Brunoni D, D'Almeida V, Perez $A B A$. Relationship between polymorphisms in genes involved in homocysteine metabolism and maternal risk for Down syndrome in Brazil. American Journal of Medical Genetics Part A.
2005;135A:263-267.

15. Chango A, Fillon-Emery N, Mircher $C$, Bléhaut $H$, Lambert D, Herbeth B, James SJ, Réthoré M-O, Nicolas JP. No association between common polymorphisms in genes of folate and homocysteine metabolism and the risk of Down's syndrome among French mothers. British Journal of Nutrition. 2005;94:166-169.

16. Acacio GL, Barini R, Bertuzzo CS, Couto EC, Annichino-Bizzachi JM, Pinto W. Methylenetetrahydrofolate reductase gene polymorphisms and their association with trisomy 21. Prenatal Diagnosis. 2005;25:1196-1199.

17. Coppede R, Marini G, Bargagna S, Stuppia L, Minichilli F, Fontana I, Colognato R, Astrea G, Palka G, Migliore L. Folate gene polymorphisms and the risk of Down syndrome pregnancies in young Italian women. American Journal of Medical Genetics Part A. 2006;140A:1083-1091.

18. Rai AK, Singh S, Mehta S, Kumar A, Pandey LK, Raman R. MTHFR C677T and A1298C polymorphisms are risk factors for Down's syndrome in Indian mothers. Journal of Human Genetics. 2006;51:278-283.

19. Scala I, Granese B, Sellitto M, Salome $S$, Sammartino A, Pepe A, Mastroiacovo P, Sebastio G, Andria G. Analysis of seven maternal polymorphisms of genes involved in homocysteine/ folate metabolism and risk of Down syndrome offspring. Genetics in Medicine. 2006;8:409-416.

20. Martinez-Frias ML, Perez B, Desviat LR, Castro M, Leal F, Rodriguez L, Mansilla E, Martinez-Fernandez ML, Bermejo E, Rodriguez-Pinilla E, Prieto D, Ugarte M; ECEMC Working Group. Maternal polymorphisms 677C-T and 1298A-C of MTHFR and 66A-G MTRR genes: is there any relationship between polymorphisms of the folate pathway, maternal homocysteine levels, and the risk of having a child with Down syndrome? American Journal of Medical Genetics Part A. 2006;140:987997.

21. Scala I, Granese B, Lisi A, Mastroiacovo P, Andria $G$. Response to "Folate gene polymorphisms and the risk of Down syndrome pregnancies in young Italian women" by Coppede et al. [2006] American Journal of Medical Genetics Part A 2007;143A:1015-1017.

22. Kohli U, Arora S, Kabra M, Ramakrishnan L, Gulati S, Pandey RM. Prevalence of MTHFR C677T polymorphism in north Indian mothers having babies with Trisomy 21 Down syndrome. Down Syndrome Research and Practice. 2008;12(2). doi:10.3104/reports.2004

23. Canfield MA, Collins JS, Botto LD, Williams LJ, Mai CT, Kirby RS, Pearson K, Devine O, Mulinare $J$ for the National Birth Defects Prevention Network. Changes in the birth prevalence of selected birth defects after grain fortification with folic acid in the United States: findings from a multi-state population-based study. Birth Defects Research (Part A). 2005;73:679-689.

24. Collins JS, Olson RL, DuPont BR, Wolff DJ, Best RG, Stevenson RE. Prevalence of aneuploidies in South Carolina in the 1990s. Genetics in Medicine. 2002;4(3):131-135.

25. Ray JG, Meier C, Vermeulen MJ, Cole, DEC, Wyatt PR. Prevalence of Trisomy 21 following folic acid food fortification. American Journal of Medical Genetics. 2003;120A:309-313.

26. Simmons CJ, Mosley BS, Fulton-Bond CA, Hobbs CA. Birth defects in Arkansas: is folic acid fortification making a difference? Birth Defects Research (Part A). 2004;70:559-564.

27. Czeizel $A E$, Puho E. Maternal use of nutritional supplements during the first month of pregnancy and decreased risk of Down's syndrome: case-control study. Nutrition. 2005;21:698-704.
28. James SJ. Maternal metabolic phenotype and risk of Down syndrome. American Journal of Medical Genetics. 2004;127A:1-4.

29. Hall JG. Re: Down syndrome and folic acid deficiency. American Journal of Medical Genetics. 2004;131A:327.

30. James SJ. Response to letter: Down syndrome and folic acid deficiency. American Journal of Medical Genetics Part A. 2004;131A328-329.

31. Hobbs CA, Cleves MA, Lauer RM, Burns TL, James SJ. Preferential transmission of the MTHFR 677T allele to infants with Down syndrome: implications for a survival advantage. American Journal of Medical Genetics. 2002;113:914.

32. Ratel D, Ravanat J-L, Charles M-P, Platet $N$ Breuillaud L, Lunardi J, Berger F, Wion D. Undetectable levels of N6-methyl adenine in mouse DNA: cloning and analysis of PRED28, a gene coding for a putative mammalian DNA adenine methyltransferase. Federation of European Biochemical Societies Letters. 2006;580:3179-3184.

33. Shovlin TC, Bourc'his D, La Salle S, O'Doherty A, Trasler JM, Bestor TH, Walsh CP. Sex-specific promoters regulate Dnmt $3 \mathrm{~L}$ expression in mouse germ cells. Human Reproduction. 2007;22(2):457467.

34. Meyer R, Wolf SS. Obendorf M. PRMT2, a member of the protein arginine methyltransferase family, is a coactivator of the androgen receptor. Journal of Steroid Biochemistry and Molecular Biology. 2007;doi10.1016/j.jsbmb.2007.05.006

35. Pant SS, Moser HW, Krane SM. Hyperuricemia in Down's syndrome. Journal of Clinical Endocrinology and Metabolism. 1968:28(4):472-478.

36. Brodsky G, Barnes T, Bleskan J, Becker L, Cox M, Patterson D. The human GARS-AIRS-GART gene encodes two proteins which are differentially expressed during human brain development and temporally overexpressed in cerebellum of individuals with Down syndrome. Human Molecular Genetics. 1997;6:2043-2050.

37. Baggot PJ, Eliseo AJ, Kalamarides JA, Shoemaker JD. A folate-dependent metabolite in amniotic fluid from pregnancies with normal or Trisomy 21 chromosomes. Fetal Diagnosis and Therapy. 2006;21:148-152.

38. Al-Gazali LI, Padmanabhan R, Melnyk S, Yi P, Pogribny IP, Pogribna M, Bakir M, Hamid ZA, Abdulrazzaq Y, Dawodu A, James SJ. Abnormal folate metabolism and genetic polymorphism of the folate pathway in a child with Down syndrome and neural tube defect. American Journa of Medical Genetics. 2001;103:128-132.

39. Matherly LH, Goldman ID. Membrane transport of folates. Vitamins and Hormones. 2003;66:403456.

40. Lubec G, Bajo M, Cheon MS, Bajova H, Matherly LH. Increased expression of human reduced folate carrier in fetal Down syndrome brain. Journal of Neural Transmission. Supplementum. 2003;(67):95-103

41. Davis SR, Quinlivan EP, Shelnutt KP, Maneval DR, Ghandour H, Capdevila A, Coats BS, Wagner C, Selhub J, Bailey LB, Shuster JJ, Stacpoole PW, Gregory JF. The methylenetetrahydrofolate reductase $677 \mathrm{C} \rightarrow$ T polymorphism and dietary folate restriction affect plasma one-carbon metabolites and red blood cell folate concentrations and distribution in women. Journal of Nutrition. 2005;135:1040-1044.

42. Fredriksen A, Meyer K, Ueland PM, Vollset SE, Grotmol T, Schneede J. Large-scale population-based metabolic phenotyping of thirteen genetic polymorphisms related to one-carbon metabolism. Human Mutation. 2007;28(9):856865 . 